\section{Special Education in 1994: Practice in Search of a Policy}

\section{LEX MCDONALD}

\section{Abstract:}

For special education in New Zealand, 1994 was a year in limbo as educators, parents and students awaited the Government's policy statement and intentions. The issues of funding and contestability of service remained central to the proposed reorganisation with considerable apprehension expressed at the direction of change. It was indicated that teachers were needing and seeking professional development in the area of special education and a number of exemplary inservice training programmes were being offered. Many special educators believe that additional training and assistance should be provided to deal with the problem of our disaffected youth but Government policy has precluded adequate interventions in this area. Research studies and projects in 1994 reflected the wide nature of the ongoing issues and concerns in special education.

f you're not going to school, you're not going anywhere" was a message that the Ministry of Education promoted in its 1994 campaign to encourage school attendance. For a number of learners however another message could have been equally applicable - "If you're going to school, you going to have to be tough!" Undoubtedly, there are numerous aspects of our society, including the education sector, that demand perseverance and resilience from our young people. But for some the demands are so overwhelming that their feelings of failure, frustration, rebellion, humiliation, depression, resentment and despair surface in the classroom. Although there may be an apparent escalating complexity of interacting forces in our community that contributes to this dysfunctioning it is important that the educational community assesses its ability to cope effectively with these children and significantly contribute to their well-being. Most educational facilities would acknowledge their responsibility to meet the needs of these learners but how effective are they in meeting the needs of all learners?
Undeniably many teachers are able to motivate and effectively support many of these learners and make a difference to their lives, while at other times it seems that little can be done to assist them. One of the significant contributing factors that relates to the effectiveness of teacher response is the support these teachers receive for the demanding professional responsibilities associated with the education of learners who have special needs. It seems timely then that a strategic plan for special education in New Zealand is to be unveiled in 1995.

\section{Blueprints for the Future?}

As the nation approaches the 21st century, the New Zealand Government has embarked upon a number of strategic plans in education to improve learning and maximise accountability. The beginning of this process was heralded in 1988 with Tomorrow's Schools (Lange, 1988) delivering considerable administrative change to the educational system. Today's Schools (Lough, 1990) followed up these changes. Since then, a number of significant plans for curriculum change such as Te Whariki (Ministry of Education, 1993a) and the New Zealand Curriculum Framework (Ministry of Education, 1993b) have emerged which will lead to specific curriculum developments. This year, a strategic plan for the education system (Ministry of Education, 1994) was announced by the Minister of Education. Plans for special education were incorporated within these statements.

In addition to this, beginning in 1987, there have also been a number of policy statements and reviews of special education (Department of Education, 1987; Ministry of Education, 1991; Ministry of Education, 1993c). Tomorrow's Schools set in place procedures for a devolution of national control of special education. In a more detailed policy proposal in 1991, that engendered considerable debate, the "Statement of Intent" outlined a number of policy principles of operation for the provision of services with an emphasis on local decision-making and maximising resource usage. In response to this document, the Minister of Education formed the Special Education Policy Implementation Team (SEPIT) to consult with professionals, parents, whanau and the community to ascertain their reactions to the proposed changes. Over 13,000 organisations and individuals were involved in this process and in the third and final consultation round in 1993 over 1,000 submissions were received. The SEPIT team submitted a report with recommendations to the Minister in August 1993. This Final Report of the Special Education Policy Implementation Team on Delivering Special Education was released to the public mid-1994 and it is believed that the Minister of 
Education, Dr Lockwood Smith, will release a policy statement sometime in 1995 (some four years after the Statement of Intent) outlining the Government's response along with a keenly awaited special education policy.

In a speech to the New Zealand Association of Special School Principals Dr Smith commented on the lack of progress in special education:

There is a valid reason for that lack of progress, of course. Being such a sensitive area it is vital to achieve such a high degree of consensus before implementing any change in special education. It is necessary to consult even more widely than is usually required in education and over a longer period of time - to ensure that what we intend to do will better meet the needs of more students. The only potential danger with consultation over too long a period of time, I suppose, is that it is possible to undermine the original sense of direction (Smith, 1994).

This delay in the reorganisation of special education has not only been frustrating but has caused anxiety and uncertainty in the service providers, parents, whanau and community groups. Undoubtedly it is a sensitive area and consultation is required, but one wonders whether it will be ever possible (or even desirable) to achieve a high degree of consensus amongst the different sector groups? The important point is to develop a policy that is sufficiently flexible to meet the differing needs of the groups. Those of us who have worked in special education for a lengthy period of time readily acknowledge the complexity of the system and the difficulty there has been in the past in attempting to accommodate some practices to the policies and standard procedures. The Minister and his advisers must be aware of this, but given the demand for a coherent and consistent government policy and the requirements of budgetary constraints, a revamped policy statement is expected to emerge with a timeline for changes. The question is not whether it will fully meet the needs of the learners and their families and whanau but how close will it come to meeting these very varied needs. It will be an approximation model of individual need. Depending on how approximate and flexible it is will determine its acceptability. Furthermore, due to the manner in which our education system is now structured, competition for resources will occur and the SEPIT report indicates that clear guidelines will need to be developed to address the issue. It should be mentioned that a key area that will be affected by the competition for resources is the question of mainstreaming. The pressure and lobby groups in special education are a powerful force and will have a significant role in shaping policy. The Government policy statement will need to be sufficiently flexible to adjust to varying demands.

It is uncertain anyhow whether the high degree of consensus that Dr Smith alludes to has been obtained by SEPIT. The final report detailing information on the questionnaire used during consultation round three, noted that:

61 percent approved in principle of the model [proposed by SEPIT],

but indicated concerns over detail. This was made up of 22 percent

who a proved of the proposal and 39 percent a pproving in principle.

39.5 percent did not approve of the proposal (Ministry of Education,

1993c:4).

However in an attached appendix there is a qualifier:

Because of the tight time constraints, all submissions were treated as being equal weight, regardless of whether they were received from individuals or from national organisations... To redress any imbalance which may therefore have occurred, members of the Implementation Team considered in detail, submissions from the national organisations (ibid (Appendix 4:2)).

No details were given in the report of the ratio of individual responses to group responses and it was not possible to estimate how many individuals were represented by group views. Furthermore, item three on the questionnaire "I approve of the proposal in principle" could have many meanings to respondents. For example, does it mean that the notion of more local decision-making is approved of, or that many specifics of this particular proposal are approved of? It was certainly difficult to match the high level of concerns (e.g., 74 percent of the questionnaires had at least one concern) with the 61 percent who approved of the model or approved in principle. Given that there has been an inappropriate data collection strategy and ambiguous wording on one of the significant questions, the validity of some of the findings should at least be questioned. Obviously there can be no certainty about a high degree of consensus.

Notwithstanding some methodological difficulties, the SEPIT consultation process was a well-intentioned project that provided an opportunity for people to have their views heard and their concerns noted about special education. Some have been concerned about the process however and have criticised the Minister for making statements that are inconsistent with the consultation outcomes. Nevertheless, the SEPIT report has carefully documented the concerns and has provided a number of recommendations for the Minister's consideration. However, it also raises many issues that require further consideration. 
For example, reviewing procedures for certain facilities are recommended; guidelines are requested to redress competition between individuals/institutions/special schools; a policy on special education is needed; funding for the proposal should be clarified; the issue of contestability needs to be clarified; a decision on the funding for the psychopaedic initiative and the 2:6 policy (two professional educators to six children with severe-profound handicap) requires urgent attention, as do all the other special education teacher:pupil ratios. Policies need to be developed for the tertiary sector and culturally appropriate practices need to be developed. This is only some of the unfinished business testimony to the complexity of special education!

Most of the expressed concerns detailed in the SEPIT report revolved around the issue of funding and the representation on the Local Special Education Resource Management Group which would have a significant part to play in the distribution of funds. It is indeed pleasing that pilot programmes in at least two areas will precede any national change and will be able to "debug" some of the problem. The issue of funding is central to special education - it ultimately determines staffing and those groups of children who receive (and don't receive) service and the quality of that service. Indeed, a significant proportion of the material in the media revolves around this issue.

Two particular concerns arose in 1994, the funding for special care units and a new policy of targeted funding for educational achievement.

The 2:6 staffing ratio established for severely disabled students in 1989 was investigated in 1994 by the Ministry of Education and it is likely that it will be unavailable for many students. Some schools have already lost this resource and students are now being placed in classes with a 1:9 teacher-pupil ratio. Obviously this must impact on the quality of education available to these students, increase demands upon the teachers in the 1:9 units and result in the loss of teacher assistant positions. The New Zealand Educational Institute (NZEI) has maintained that current staffing levels should be maintained until a satisfactory solution is found:

We have tried to get the Ministry of Education to discuss the issues and negotiate a more permanent staffing arrangement for the past four years. All children must be entitled to feel safe at school and receive the appropriate education. By cutting staff and simultaneously refusing to discuss the issue, the Ministry is doing parents, teachers and children a gross disservice (Duncan, 1994:7).

Funding for students with low achievement in inclusive educational settings has also been changed. The learning assistance and equity grants are to be replaced with targeted funds and a socio-economic indicator has been developed based on census data and roll returns. To many this seems a fairer system than a system that at times depended upon the principal being able to write a convincing case. But there has been some disquiet expressed about this change, for there seems to be no provision for those students who have significant learning disadvantage (e.g., where low achievement is masked by the high socio-economic ranking of the school). The point being made is that there are pockets of low achieving youngsters in well-to-do areas and vice versa. The individually targeted funding may be available for some of these learners but in the past these learners have not been eligible. Should the schools with a higher socioeconomic ranking provide the resources needed for these children or should there be available funds via the Ministry? It is suggested that a safety net provision with strict criteria for documented cases be implemented. Further, recommendations of a small group of local principals, for documented cases, could ensure equity for all schools.

The difficulty with funding is that it costs money! The means of determining who benefits from the different funding arrangements is a hot potato and has always generated heated discussion. It is unlikely that the latest attempt by David Mitchell and Ken Ryba (Mitchell, 1994), contracted by the Ministry of Education to formulate an acceptable criterion of eligibility for special education resources will fare any better.

Another debate has centred on who should provide service. The issue of contestability is like the soap opera "Shortland Street". You hate it, or passionately support it. It has a murky plot based upon inadequate logic and sloppy style and questions of when? how much? and what happens next? will plague us for some time to come. It is not the intention in this review to consider in any detail the issue of contestability which has been addressed by Anne Meade (1992). Suffice to say that the question of contestability is still around. The Government continues to support it (somewhat more shakily) and service providers and parents on the whole are either vehemently opposed to it or sceptical of its ability to provide adequately for learners with special needs. The latest announcement from the Minister is that the Special Education Service would become partly contestable in 1995 and fully contestable in 1996. This has rekindled opposition:

The Special Education Service is a bulk funded agency. The Ministry negotiates each year to purchase hours. The SES can only provide the hours purchased. It is not a needs-based service. 
With the introduction of contestability, providing services to those who need them would become like a lottery..

My rough calculations show that if the money spent on the SES was devolved to schools, early childhood centres and tertiary institutions, it would come to about 1.5 hours of SES a week for a school with 300 students (Davies, 1994:3).

Unfortunately, service to schools and facilities has diminished since 1989 and the prospect of contestability has nudged the SES to seek contracts with other government agencies, and this at a time when there is unprecedented demand for assistance with learners who have difficulties in the schools.

What will the next episode bring? Will the series be canned? The prediction is that it will be a fizzer and a "Clayton's" contestability will feature. Watch next year!

\section{Teacher Education}

The Special Education Service has in the past contributed significantly to the professional development of teachers but teacher inservice training in the current contract year was significantly reduced and other services purchased by the Ministry. Accordingly, many courses have become cost recovery. It is likely that the notion of contestability of inservice funding brought about this change based upon the assumption that a service provider should be responsive to the client's needs. To many this has seemed a somewhat short-sighted decision. Not only are there funding difficulties for many schools, but in the absence of continued inservice training needs analyses, there is difficulty for many special education teachers on regular education sites to express their need for professional development. Special Education Service workers often have a close relationship with their teachers and consideration of inservice training needs occurs frequently. Furthermore, many of the mainstream teachers wishing to undertake courses in special education find it difficult to access towns and cities where colleges of education offer courses, and anyhow many teachers in urban areas prefer brief courses to the Advanced Studies for Teachers (AST) college papers. The competitive environment thrust upon the different service providers precludes cooperative training ventures for most institutions. Renaut (1994), on the basis of a survey, has made a plea for a systematic approach to inservice teacher training.

1994 was an important year in professional development for a number of teachers however.
Numerous workshops and lectures at the local, regional and national levels provided opportunities for teachers and other professionals to update their knowledge and competencies in special education. A number of distinguished overseas educators visited New Zealand: both Art Costa and John Edward presented workshops on thinking skills; Lilli Nielsen helped teachers, parents and professionals to work more effectively with the severely and multiply handicapped, visually impaired learner; and Douglas Carnine gave a keynote address on direct instruction to the New Zealand Special Education Association national conference; Pat Mirenda presented a lecture on augmentative communication for persons with severe intellectual disability; Paula Square considered the role of the speech-language therapist in developmental apraxia; and Dr Christy Ludlow, a visiting lecturer in speech pathology, delivered a number of lectures on voice and fluency.

The year proved fruitful for professional development in the extension of programmes for regular class teachers. While mainstreaming has been a feature of New Zealand's education system for a very long time, and in recent years has been a focus for activity, preparation of regular class teachers has not received the attention it has deserved. Regular classes will not be inclusive environments until most, if not all, teachers have the strategies to make them so.

The development of resources in co-operative learning and thinking strategies has been a feature of work for both primary and secondary teachers in the areas served by Wellington and Palmerston North Colleges of Education. In Wellington, the School of Special Education has developed a number of intensive courses for primary teachers which have attracted some hundreds of teachers. The courses deal with cooperative classrooms, management of behavioural difficulties and strategies for learning.

At both Wellington and Palmerston North Colleges, Don Brown, a former chief psychologist and director of special education, has developed courses for secondary teachers in strategies for success in both teaching and learning. These courses have attracted over 300 teachers. The Ministry of Education has seen the potential to tie these courses to the current curricula initiatives. The emphasis in the new curricula on thinking and information processing is a very neat match with the courses already being developed. In 1994 a contract was let to Don Brown and Charlotte Thomson, Director of Special Education at the Wellington College of Education, to create a cadre of teachers in strategic teaching methods and co-operative learning. This programme will continue through 1995. The purpose is to ensure there is a significant 
number of teachers capable of ensuring the new curricula are delivered in a fashion which is appropriate to the demands of the preferred teaching styles.

\section{Disaffected Youth}

In the Year of the Family in New Zealand there was unprecedented reporting of the plight of youth and their alienation from society At a time when the Special Education Service was seeking contracts from outside the education sector, there were alarming indices of youth social disorganisation. Reports of increasing truancy, violence and suicide abounded. Although it must be acknowledged that there are no simple explanations or solutions to these dysfunctional behaviours, the responsibility of the education system cannot be disregarded. Prevention and intervention programmes are recognised as national priorities by many educationalists, families and whanau, but piecemeal efforts and an ambivalence of responsibility by the Ministry of Education prevent an adequate response in the schools.

Gordon (1992:300) has provided an insight into the politics of truancy and made a number of well-formulated suggestions for tackling the problem but concluded:

The media attention of 1992 was brought about by claims of increasing truancy in a number of regions and schools. The policy response to this problem failed to provide any constructive solutions. We can expect, then, that 1992 will not have seen the end of the truancy problem; before long, it will be back as an issue in the media.

The problem has continued to have a high profile. Following considerable coercion the Government established a select committee in 1994 to inquire into children at risk, the intention being to gather information and identification data and assess educational strategies for children at risk of truancy and behavioural problems.

In the meantime the Ministry of Education has funded a number of community-based truancy programmes and some voluntary community worker truancy programmes are assisting students back into school. For schools in these districts this is a positive step but most school principals are still seeking answers to the problem and a nationwide response by the Ministry:

A number of people involved with students, through school and other services, are calling for a more unified, proactive approach to truancy and other at-risk behaviour.

No government agency has control of the problem yet a Ministry of Education report, on truancy, based on a survey of 23 schools, repeatedly states there is a lack of resources and time available to deal with truancy and related problems.

Even the basics are missing, such as a national data base on school enrolment (McCarthy, 1994).

Many reports have also alluded to an increasing and disturbing trend in violent behaviour at school. The maladaptive impact on the aggressor and the victim is well documented and although there is limited data on bullying and violence in our schools there is growing evidence to suggest that we should be concerned. For example, a Primary Principals Federation survey in 1992 indicated that bullying was getting worse and, more recently, the Manakau North Special Education Service conducted pilot research into bullying in three schools and discovered that 80 percent of all students had been bullied within the previous three months. In 1994, following a significant outcry in the media, the Commissioner for Children investigated violence in a select Christchurch private school and concluded that it was bordering on criminal behaviour and he urged swift action to remedy the problem.

In response to this violence in schools, the Kia Kaha and Healthy Schools programmes have been developed for classroom use and the Ministry of Education is speed-tracking curriculum development to provide support to teachers to develop effective strategies. Under the direction of Christine Hilton-Jones the Manukau North Special Education Service has developed a comprehensive school-wide training package for teachers. This programme has been well received by schools and is impacting on the problem but because of the funding arrangements this is only available on a cost-recovery basis. Some schools obviously do not have the funds to purchase the programme and will therefore be denied assistance to halt the abuse and harm that many students are subjected to.

For some of our youth, the alienation from society is so intense that the consequences are disastrous. Increasingly New Zealand youth, particularly males, are taking their lives. Teenage suicides in New Zealand are three times higher than 20 years ago and are the highest in the industrialised world. In response to these alarming statistics the Government initiated the Youth Mental Health and Suicide Prevention Project and this year it presented its final report (Ministry of Health, 1994). It identifies a number of agencies which should, together, be able to impact on this problem and reduce the incidence of suicide.

Although suicide may be related to poor mental health it is a social problem and prevention is the responsibility of our community, including the education sector. Accordingly, the Ministry of Health 
report recommends that the Ministry of Education (Recommendation 2):

...include(s) in its contract with the Special Education Service, specific outputs that relate to the mental health needs of young people. Such outputs should cover issues relating to specialised support and counselling for mental, emotional, behavioural and addiction concerns, including support for young people who identify as gay or lesbian, and (provide) for the support and education of parents. It would include:

- the development of a comprehensive package for every school to assist them with the identification and support of students whose mental health is at risk;

- consultation with other mental health professionals to develop a training package which ensures that school staff are provided with the skills to deal with a sudden death within the school population;

- the availability of extra services to secondary school students who have emotional, mental health, relationship or social concerns. This would include direct counselling and assessment of students who have been abused, have major addiction problems or suspected mental illness;

- the availability of Special Education Service staff to advise schools and to support students following a sudden death or attempted suicide that involves a staff or student member of the school community (Ministry of Health, 1994:41).

The Ministry of Education response was somewhat predictable.

The Ministry notes that in the current outputs negotiated with the Special Education Service, the Ministry would not specify particular tasks as described in Recommendation 2. It points out that the chief focus of the Special Education Service is the learning needs of the students. While such areas as thoseidentified in the recommendation are not excluded from the work of the Special Education Service, the Ministry would expect new money to be provided to service this additional output. It notes that the Special Education Service is able to pick up outputs from agencies other than Education, and suggests that a preferred option might be for the Public Health Commission to purchase services from the Special Education Service to fulfil the requirements outlined in Recommendation 2 (p. 43).

There are two significant points to be made here: the contractual funding approach effectively compartmentalises student behaviour and the Ministry of Education overlooks survival as a basic human learning response. Even if suicide could be dismissed as being unrelated to learning needs, one of the functions of the Special Education Service is to assist families with non-educational-related difficulties in their functioning(Ministry of Education, 1991). The 1989 Education Act clearly states that the Special Education Service is to provide guidance, advice and support to people with difficulties in learning and development (writer's italics). To deny the full support of services to schools for suicide prevention is a tragedy for students, their family and whanau, their teachers, the community, and the nation.

\section{Research, Projects and Developments}

Much of the research in special education in New Zealand over the years has emanated from the universities. With the professionalisation of special education, however, there has been a growing interest by teachers in applied research. Furthermore there has been a shift in methodology with considerably more qualitative and participant-driven studies initiated.

Without doubt there is considerable ongoing research and project development occurring in special education. For example, at Otago University a group of researchers (Harris, Rowlands, Ballard, Smith \& Gleeson, in press), two of whom have direct experience of disability have been investigating the experiences of students who have a disability in a tertiary setting, the intention being to identify what is supportive and what barriers are encountered. The research of Ken Wilton (Auckland University) and Des Pickering (Deakin University, Victoria, Australia) for the New Zealand Association of Special School Principals was initiated in 1994 and will prove invaluable for the compilation of national data on special school population and programme effectiveness. It aims to describe the population of the students, identify the levels of service provision necessary and determine the extent of health service provision. The purpose is to determine support level requirements for integration, evaluate current service, assess curriculum needs and identify the reasons why parents opt out of inclusive education settings.

Another applied research project, contracted by the Ministry of Education to Charlotte Thomson at the Wellington College of Education, is concerned with the use of individual educational plans (IEP) in schools. This research will evaluate the use of IEPs in educational settings and provide valuable guidelines for the their future use and the development of programmes for learners with special needs. Kerslake and Dewar (1994), in a research project for the colleges of education and the Ministry of Education, undertook a survey of the qualifications of special education teachers and analysed possible future training needs. The results of this research will be helpful when determining training needs. 
One of the exciting developments in the past few years has been growth of teacher research and teacher-initiated project development. At the Christchurch College of Education Chris Dowson, senior lecturer in deaf studies, has instigated a number of research programmes with teachers. During 1994 teachers undertook research in a number of areas, e.g., developing literacy through faxes with deaf adults, the cognitive components in mother-child interaction, the children of deaf adults, tertiary provision for deaf learners, auditory input for cochlea implant children, the CHARGE syndrome and case studies on the literacy skills of deaf learners. The National Foundation of the Deaf has also undertaken research on tertiary provision.

Research by postgraduate teachers at the Wellington College of Education has centred on learners in inclusive educational settings. Dissertation research projects for 1994 included studies of Assertive Discipline (Creet, 1994; Sinclair, 1994), cognitive strategy instruction and attribution training in the writing process (Press, 1994), reciprocal teaching and comprehension (Eastwood, 1994), tutee selection of peer tutors (Brydges-Jones, 1994), individual development plans in kindergartens (Mackenzie, 1994), the use of a concept keyboard with a learner with significant learning difficulties (Drew, 1994) and social skills training programmes for pre-adolescents (Taplin, 1994). In an interinstitutional research programme with Wellington College of Education and the Cook Islands Teachers' College, Lex McDonald and Terepai Moetaua have developed a framework for the development and evaluation of a special education teacher development programme in the Cook Islands. Preliminary data for this research project has been collected and inservice training programmes are scheduled to begin in 1995. Both Paterson (1994) and Sweeney (1994) assisted with the pilot work for this project.

Increasingly, there has been a demand for a cultural sensitivity, understanding and provision for the needs of Maori and Pacific Island students in special education. Accordingly, the establishment of a marae for Maori deaf and a bilingual-bicultural language nest at the Kelston Deaf Education Centre (with one being planned for van Asch College in Christchurch) have been very welcome. It is hoped that such developments will be supported and promoted and extended to other cultural groups in New Zealand and that research studies will follow.

\section{Conclusion}

In many respects 1994 was been a "wait and see" year for special education. With the backdrop of growing disquiet since Tomorrow's
Schools it will be somewhat of a relief to have a strategic plan for special education although it may be a mixed blessing. At least the cards will be on the table and forward planning could be launched with a degree of confidence. On the other hand, many of the sector groups believe that the task is immense and are concerned that it will be an inconsistent policy lacking in philosophy and clear direction and accordingly will be of dubious assistance to special education as it approaches the 21st century.

\section{References}

Brydges-Jones, J. Peer Tutoring: Tutor Selection in a Secondary School Reading Programme, Wellington: Wellington College of Education, 1994.

Creet, J. An Evaluation of Assertive Discipline's Role in Classroom Management: A Case Study, Wellington: Wellington College of Education, 1994.

Davies, J. "Strong Opposition to Government Plans for SES", in NZEI Rourou, 5:13, 1994:3.

Department of Education. Draft Review of Special Education, Wellington: Department of Education, 1987.

Drew, C. A Case Study: The Use of a Concept Keyboard to Increase the Independent Writing Skills of a Student with Learning Difficulties, Wellington: Wellington College of Education, 1994.

Duncan, H. "Staffing Cuts Threaten Special Care Units" in NZEI Rourou, 5:15, 1994:7.

Eastwood, C. "Reciprocal Teaching: A Strategy to Assist Students to Gain Meaning from Text", Wellington: Wellington College of Education, 1994.

Gordon, L. "The Politics of Truancy in 1992", in H. Manson (ed) New Zealand Annual Review of Education: 2:1992, Wellington: Victoria University of Wellington, 1992:285-301.

Harris, D., Rowlands, M., Ballard, K., Smith, K. and Gleeson, B. Disability and Tertiary Education: A Study in Three Settings, in press.

Kerslake, J. and Dewar, S. “Special Education Qualifications and training: An Account of Qualifications Presently Held by Special Education Educators and an Analysis of Possible Future Training Needs", in The Research Bulletin, 3, 1994:95-113.

Lange, D Tomorrow's Schools: The Reform of Education Administration in New Zealand, Wellington: Government Printer, 1988. 
Lough Report: Today's Schools, Wellington: GP Print, 1990.

McCarthy, A. “Battle to Keep Kids in School”, Sunday Star-Times, July 31, 1994.

Mackenzie, B. Implementing Individual Developmental Plans in Kindergartens: Teachers' Perceptions, Wellington: Wellington College of Education, 1994.

Meade, A. "Contestability in the special education and early childhood sectors: a mechanism for countering equity?" in H. Manson (ed), New Zealand Annual Review of Education 2:1992, Wellington: Faculty of Education, Victoria University

Ministry of Education. Special Education in New Zealand: Statement of Intent, Wellington: Ministry of Education, 1991.

Ministry of Education. Te Whariki: Draft Guidelines for Developmentally Appropriate Programmes in Early Childhood Services, Wellington: Ministry of Education, 1993(a).

Ministry of Education. The New Zealand Curriculum Framework, Wellington: Ministry of Education, 1993(b).

Ministry of Education. Final Report of the Special Education Implementation Team on Delivering Special Education, Wellington: Ministry of Education, 1993(c).

Ministry of Education. Education for the 21st Century, Wellington: Ministry of Education, 1994.

Ministry of Health. Report and Recommendations of the Steering Group on Youth Mental Health and Suicide Prevention, Wellington: Ministry of Health, 1994.

Mitchell, D. "Who Needs What Educational Support?" Paper presented at the New Zealand Special Education Association Conference, Christchurch: August 1994.

Paterson, S. Teacher Inservice Preferences: A Wainuiomata Survey, Wellington: Wellington College of Education, 1994.

Press, R. Cognitive Strategy Instruction and Attribution Training in the Writing Process, Wellington: Wellington College of Education, 1994.

Renaut, J. “Special Education Service Delivery in the Canterbury, Nelson, Marlborough and Buller Westland Regions". Paper presented at the NZARE Conference, Christchurch: December 1994.

Sinclair, L. Playground Discipline: What is Actually Happening in the School Playground? Wellington: Wellington College of Education, 1994.
Smith, L. Address by Minister of Education, Hon. Lockwood Smith to New Zealand Association of Special School Principals, Auckland: July 1994.

Sweeney, M. Developing Participatory Methodology for a Cook Islands-New Zealand Special Education Teacher Training Initiative, Wellington: Wellington College of Education, 1994.

Taplin, E. Empowering Pre-Adolescents via Social Skills Training, Wellington: Wellington College of Education, 1994.

\section{The author}

Lex McDonald has been a teacher and psychologist and is employed as a senior lecturer in the School of Special Education at the Wellington College of Education. He is currently writing a $\mathrm{PhD}$ thesis on special education teacher inservice in the Cook Islands. 